\title{
Legal Regulation of Hydrogen in Germany and Ukraine as a Precondition for Energy Partnership and Energy Transition
}

\author{
Maryna Hritsyshyna *(D) and Nataliia Hutarevych \\ Sayenko Kharenko Law Firm, 01001 Kyiv, Ukraine; hn@sk.ua \\ * Correspondence: mhr@sk.ua
}

Citation: Hritsyshyna, M.;

Hutarevych, N. Legal Regulation of

Hydrogen in Germany and Ukraine

as a Precondition for Energy

Partnership and Energy Transition.

Energies 2021, 14, 8331. https://

doi.org/10.3390/en14248331

Academic Editor: Nikolaos E.

Koltsaklis

Received: 12 November 2021

Accepted: 6 December 2021

Published: 10 December 2021

Publisher's Note: MDPI stays neutral with regard to jurisdictional claims in published maps and institutional affiliations.

\begin{abstract}
In August 2020, Germany and Ukraine launched an energy partnership that includes the development of a hydrogen economy. Ukraine has vast renewable energy resources for "green" hydrogen production and a gas transmission system for transportation instead of Russian natural gas. Based on estimates by Hydrogen Europe, Ukraine can install 8000 MW of total electrolyser capacity by 2030. For these reasons, Ukraine is among the EU's priority partners concerning clean hydrogen, according to the EU Hydrogen strategy. Germany plans to reach climate neutrality by 2045 , and "green" hydrogen plays an important role in achieving this target. However, according to the National Hydrogen Strategy of Germany, local production of "green" hydrogen will not cover all internal demand in Germany. For this reason, Germany considers importing hydrogen from Ukraine. To govern the production and import of "green" hydrogen, Germany and Ukraine shall introduce legal regulations, the initial analysis of which is covered in this study. Based on observation and comparison, this paper presents and compares approaches while exploring the current stage and further perspectives for legal regulation of hydrogen in Germany and Ukraine. This research identifies opportunities in hydrogen production to improve the flexibility of the Ukrainian power system. This is an important issue for Ukrainian energy security. In the meantime, hydrogen can be a driver for decarbonisation according to the initial plans of Germany, and it may also have positive impact on the operation of Germany's energy system with a high share of renewables.
\end{abstract}

Keywords: green hydrogen; renewable energy; energy transition; electrolyser; Germany; Ukraine; energy partnership

\section{Introduction}

On 26 August 2020, Ukraine and Germany signed a Joint Declaration of Intent on the Establishment of Energy Partnership. This energy partnership covers different areas, including energy efficiency, renewable energy, decarbonisation and others. However, one of the most discussed topics is the hydrogen economy [1].

Discussions of cooperation perspectives between Germany and Ukraine on the hydrogen economy commenced before the conclusion of the Joint Declaration between the countries. At the end of 2019, Germany and Ukraine held negotiations regarding hydrogen energy cooperation [2]. However, after the establishment of the energy partnership, such discussions have been initiated with increasing frequency.

It should be noted that the energy partnership between Germany and Ukraine does not cover all issues of green hydrogen use. The energy partnership focuses only on issues regarding green hydrogen production and the realisation of initial projects in Ukraine together with German companies [3]. At the same time, important issues such as the legal regulation of hydrogen in Ukraine remain beyond the framework of this cooperation.

This work analyses the perspectives for German-Ukrainian energy partnership regarding green hydrogen production as one of the most important issues of this partnership. The energy partnership between Germany and Ukraine is based on certain preconditions. As a country with an area of $603,628 \mathrm{sq}$. km, Ukraine has incredible renewable energy potential 
for green hydrogen production. For this reason, the EU considers Ukraine a partner in strategic hydrogen studies and reports. At the same time, Germany has a large demand for green hydrogen that must be covered partially by imports.

This paper considers the renewable energy potential and issues with the flexibility of the energy system of Ukraine for additional deployment of the renewable generation for hydrogen production. According to information provided by the Ukrainian TSO, the installed capacity of renewables in October 2021 was $7954.60 \mathrm{MW}$ [4], or 14.18 percent of the total installed capacity of the Ukrainian united power system, which is 56,067.40 MW. However, the current installed capacity of renewables is a small part of Ukraine's potential. According to the data presented in the atlas of energy potential of renewables, Ukraine has a renewable energy source (RES) potential of $874 \mathrm{GW}$. Based on this research, the general potential for annual hydrogen production in Ukraine is 505,133 million cubic meters or 44,597 thousand tons [5].

Meanwhile, Germany has the largest hydrogen demand in the European Economic Area, equalling 22 percent of all demand. In 2018, the demand for hydrogen in Germany was over 70 TWh [6]. According to the National Hydrogen Strategy of Germany, by 2030 this demand will increase around 90 to 110 TWh [7].

Notwithstanding a 46.3 percent renewables share in gross electricity consumption in Germany in 2020 [8], the country will not be able to cover increased demand for hydrogen by internal production alone and plans to import green hydrogen. To achieve this, the German National Hydrogen Strategy includes an action plan with 38 measures that also includes international cooperation and partnership with other countries [7].

Taking into account the RES potential of Ukraine, Germany is exploring the possibility of producing hydrogen in Ukraine with transportation through the Ukrainian gas pipeline network [9]. However, to produce green hydrogen for export to Germany, Ukraine must ensure the development of renewable generation and installation of electrolysers. Pursuant to the green hydrogen initiative for the European Green Deal, by 2030 Ukraine must have $8000 \mathrm{MW}$ of electrolyser capacities for hydrogen to supply it to the EU, and $1800 \mathrm{MW}$ for ammonia for the domestic market [10].

Construction of all electrolyser capacities in Ukraine by 2030 will require the deployment of renewable projects. However, this will only be possible if the country is able to attract the required amount of investment.

According to the Green Hydrogen Investment and Support Report, Ukraine will need EUR 20.1 billion investments under the Table 1.

Table 1. Investments in solar, wind and electrolyser capacity for green hydrogen production in Ukraine [11].

\begin{tabular}{ccc}
\hline & Ukraine, MW & Ukraine, Billion Euro \\
\hline Electrolysers & 10,000 & 3.5 \\
\hline Onshore Wind & 11,100 & 13.3 \\
\hline Solar PV & 11,100 & 3.3 \\
\hline Total & & 20.1 \\
\hline
\end{tabular}

Despite the existing demand in Germany and Ukraine's potential for the hydrogen production, there are many challenges for the realisation of hydrogen projects within the framework of the German-Ukrainian partnership.

This paper aims to analyse the main barriers in legal regulations in Ukraine and Germany to the realisation of green hydrogen projects for the purposes of the Joint Energy Partnership and German energy transition goals. At the same time, this paper includes analysis of possible ways to improve the flexibility of Ukraine's energy system as one of the potential obstacles to increasing renewable generation for green hydrogen production.

According to an online survey within 20 representatives of German companies organized, based on the German-Ukrainian Energy Partnership, the main restrictions for 
the development of hydrogen projects are uncertainty with consumers for the hydrogen, funding of projects in Ukraine with high political risks and a low level of profitability, lack of legal rules for hydrogen production in Ukraine, and uncertainty as to the logistic issues for produced hydrogen [3].

In order to also have the opinion of representatives of Ukrainian companies for the purpose of this paper on the basis of the Ukrainian Wind Energy Association, an online survey regarding the perspectives of green hydrogen projects and obstacles to their realisation in Ukraine was organised. The key results of this survey are described in this paper.

Energy partnership in the area of hydrogen opens up significant export opportunities for Ukraine and Germany, not only for produced hydrogen but also for new technologies. In the meantime, the successful use of new hydrogen technologies is possible only on the ground of the regulatory framework and effective cooperation between businesses in both countries.

In terms of novelty, the main contributions of the current study are:

i. Comprehensive analysis of the current level of legal regulation in the field of green hydrogen production in Germany and Ukraine, which identifies risks for the energy partnership between the countries and explores measures for their reduction or elimination;

ii. Review of the impact of the German-Ukrainian energy partnership in terms of hydrogen production for the improvement of power system flexibility under conditions of energy transition;

iii. Presenting the results of a survey among market participants representing RES generation in Ukraine, which identifies obstacles to the development of green hydrogen projects and hydrogen partnership with Germany.

An important element of this paper and its novelty constitutes analysis of possible ways to improve the flexibility of Ukraine's energy system by means of the use of electrolysers for green hydrogen production for:

- Balancing renewables on the electricity market; and

- $\quad$ Reducing renewables curtailments.

Analysis of the possible methods for improvement of the flexibility of Ukraine's energy system with the use of electrolysers has not previously been performed, and for this reason this paper includes quite new issues and conclusions for the energy system of Ukraine.

\section{The State of Legal Regulation of Green Hydrogen in Germany and Ukraine}

\subsection{Legal Regulation in Germany}

Considering the legal regulation of hydrogen in Germany, it shall be mentioned that hydrogen technology is regulated at the EU and Member States levels. The development of hydrogen in the EU is based on a number of strategic documents. First of all, hydrogen is essential for climate-neutrality targets under the European Green Deal [12]. For the development of the hydrogen production in the EU, the following documents with hydrogen perspectives were adopted:

- Updating the 2020 New Industrial Strategy that includes hydrogen in the strategic areas and hydrogen projects that can be realised as Important Projects of Common European Interests [13];

- NextGenerationEU states that clean hydrogen projects will be funded within the framework of the new Strategic Investment Facility [14];

- $\quad$ The EU Hydrogen Strategy presents the prospect of hydrogen deployment in the EU till 2030 with analysis of possible obstacles [15].

Except for strategy documents, some regulations of hydrogen are included in the following EU legislative acts: 
- Directive 2014/94/EU on the deployment of alternative fuels infrastructure that determines hydrogen as an alternative fuel that helps to substitute fossil fuel and can lead to transport sector decarbonisation [16];

- Directive (EU) 2018/2001 on the promotion of the use of energy from RES that mentions the importance of covering hydrogen by guarantees of origin that apply to renewable gas [17].

According to the HyLaw report [18] the following EU directives have an impact on the hydrogen production:

- Directive 2012/18/EU on the control of major accident hazards involving dangerous substances that determines hydrogen as a dangerous substance with qualifying quantity for lower-tier requirements and upper-tier requirements [19];

- Directive 2014/34/EU relates to equipment and protective systems intended for use in potentially explosive atmospheres that can be applied to equipment of the hydrogen production plants [20];

- Directive 2010/75/EU on industrial emissions that includes requirements for hydrogen production [21].

At the same time, alongside hydrogen production, at the EU level it is highly important to regulate infrastructure issues like pipeline networks, and market rules for hydrogen. Regarding market rules, it is possible to implement the same approach as to the gas market regulation [22], but this approach is only at the stage of discussions and proposals.

Notwithstanding a lot of legal acts regulating hydrogen at the EU level, the HyLaw report concludes that the main obstacles for hydrogen deployment connected with a lack of proper harmonisation of regulations and discrepancy of the regulations in the national legislation that is not connected with regulation at the EU level [18].

According to the Green Hydrogen: A Guide to Policymaking from IRENA [23], the national policies for hydrogen economy shall be based on the following main regulations:

- National hydrogen strategy;

- $\quad$ Policy priorities for hydrogen;

- $\quad$ Guarantee of origin schemes; and

- Enabling policies.

\subsubsection{National Hydrogen Strategy}

Germany has made significant progress in the development of policy for green hydrogen. In the middle of 2020, Germany published its Hydrogen Strategy [7] that includes not only goals and ambitions regarding the hydrogen economy, but also an action plan with 38 measures.

\subsubsection{Policy Priorities for Hydrogen}

The possibility of using hydrogen in different sectors and industries depends on infrastructure availability. According to IRENA, countries have different levels of development for different sectors of hydrogen projects and Germany, in contrast with other countries, is concentrated on possible options for hydrogen transportation through the natural gas pipeline [23]. For instance, in 2020, the German gas pipeline operator presented the concept of a project involving the largest pipeline for hydrogen with a length of $5900 \mathrm{~km} \mathrm{[24].}$

Moreover, after the publication of the National Hydrogen Strategy, the German Federal Network Agency (Bundesnetzagentur) organised a consultation with market participants from 13 July 2020 to 4 September 2020 regarding hydrogen networks regulation [25]. According to the results of this consultation, there were different opinions regarding the regulation of hydrogen. However, most stakeholders supported the idea of new regulation through a separate law for hydrogen infrastructure [25].

In other words, all these facts evidence the policy priorities of Germany regarding infrastructure for the transportation of green hydrogen. 


\subsubsection{Guarantee of Origin Schemes}

Hydrogen as a chemical element has characteristics that do not depend on the production method and the determination of its origin is impossible. For this reason, it is highly important for the hydrogen market with different categories of hydrogen depending on the source of production to have "a traceability system [26]" as certain rules for confirmation of its origin, such as a guarantee of origin scheme.

Guarantee of origin schemes are implemented in the EU at national and EU levels [27]. A guarantee of origin can confirm production of green hydrogen with the use of renewable energy. At the EU level, a lot of guarantees of origin bodies and schemes exist, but they work under different procedures and standards that lead to problems due to the lack of a unified definition of "green hydrogen" in the EU [27].

Meanwhile, the first guarantee of origin for green hydrogen was issued at the EU level by CertifHy in 2018 [28]. By the end of 2020, CertifHy provided 2900 guarantees of origin for 86 tonnes of green hydrogen [29]. It should be noted that the growth of use of the CertifHy scheme for issuance of guarantees of origin for green hydrogen is expected [29].

On the national level in Germany, two bodies-Clean Energy Partnership and TUV SUD—provide certificates of origin, but only for "grey" hydrogen [27].

According to measure No. 30 of the German National Hydrogen Strategy, confirmation of origin for electricity from RES and green hydrogen is important for the development of the hydrogen market. At the same time, it emphasises that all standards for hydrogen shall be at the EU level to establish an international hydrogen market [7].

Thus, regulation of the issuance of guarantee of origin certificates in Germany depends on the development of EU regulation of this issue.

\subsubsection{Enabling Policy}

Hydrogen projects can obtain funding in Germany at the national and EU level. In May 2021, Germany announced the realisation of 62 hydrogen projects with state funding of EUR 8 billion [30]. It should be noted that this financial state support shall be used mostly for the construction of electrolysers and hydrogen pipelines. At the EU level, on 22 June 2021, Germany received funding for hydrogen projects as part of the European initiative of the EU Important Project of Common Interest ("IPCEI") of EUR 1.5 billion under the recovery and resilience plan [31], approved by the European Commission with general funding of EUR 25.6 billion [32].

In other words, Germany has the funds and budget for the realisation of hydrogen projects and especially for IPCEI. However, to commence the realisation of any project with new products, it is crucial to have at least the main definitions of this product determined in legislation.

\subsubsection{Definition of "Green Hydrogen"}

After approval of the National Hydrogen Strategy, Germany commenced work on the preparation of a legal framework for hydrogen production. One of the main issues of this work is the legal definition of "green hydrogen".

The German National Hydrogen Strategy defines the following types of hydrogen on the basis of the production conditions:

- "grey hydrogen" is produced from natural gas by means of reforming;

- " "blue hydrogen" is produced with the use of carbon capture;

- " "green hydrogen" is produced from water by means of electrolysis with the use of electricity from RES;

- " "turquoise hydrogen" is produced through the thermal splitting of methane [7].

On the national level in Germany, "green hydrogen" is defined in the Ordinance on the Implementation of the RES Act 2021 and in the Amendment of Other Energy Regulations ("Ordinance on the Implementation of EEG 2021") of the Federal Government (Bundesregierung) dated 19 May 2021 [33]. The Ordinance on the Implementation of EEG 
2021 includes the requirements for green hydrogen for exemption of surcharge payments under the RES Act (Erneuerbare-Energien-Gesetz-“EEG 2021" [34]).

In the meaning of the Ordinance on the Implementation of EEG 2021, green hydrogen shall be produced electrochemically by the exclusive consumption of electricity within the first 5000 full-load hours of a calendar year in a facility for the green hydrogen production. Production of the green hydrogen shall be based on the electricity:

- Generated from RES in the meaning of the EEG 2021;

- From installations located in the price zone of Germany of at least 85 percent and from installations located in a price zone that is electrically connected with Germany by 15 percent, and

- Produced without supportive scheme under the EEG 2021, the Ordinance on the Implementation of EEG 2021 or under the Act on Combined Heat and Power in the version applicable to the installations or without any other support [33].

Where the renewable energy sources under the EEG 2021 include (a) hydropower; (b) wind and solar energy; (c) energy form geothermal sources; (d) bioenergy [34].

The Ordinance on the Implementation of EEG 2021 also contains requirements for confirmation that electricity used for green hydrogen production is from renewable energy sources. In case of the supply of electricity through the grid production from RES, it shall be confirmed through the guarantees of origin for RES or, in the case of electricity consumption that is not transmitted through a grid, the electricity produced from RES shall be consumed in the facility for the production of green hydrogen during each 15-min interval of electricity generation [33].

In the meantime, the definition of "green hydrogen" is not yet determined at the EU level [26]. Due to this uncertainty, the Federal Government (Bundesregierung) shall revise requirements for green hydrogen within the scope of application of the surcharge payment exemption under the EEG 2021 without any delay after determining the requirements for green hydrogen in the EU. The main idea of this approach is explained in the Ordinance on the Implementation of EEG 2021 as the aim to have requirements that are as uniform as possible for all uses of green hydrogen, and such conditions shall ensure the operation of facilities for the production of green hydrogen with all requirements [33].

It should be noted that the requirements for green hydrogen in the Ordinance on the Implementation of EEG 2021 were determined only to introduce surcharge payment exemption for hydrogen under EEG 2021 like a stimulation scheme for green hydrogen production.

Therefore, according to German law, green hydrogen is hydrogen produced by electricity from RES based mostly on the territory of Germany and without any supportive scheme.

\subsubsection{Supportive Schemes for Production}

Green hydrogen production is based on the division of water into hydrogen and oxygen in an electrolyser that runs on renewable electricity. For this reason, costs of green hydrogen production consist of the capital costs or CAPEX for construction of the electrolyser and operational costs, or OPEX, for electricity and water for the production process [35]. At the current stage of technology development, the costs for green hydrogen production are higher by 2-4 times than the costs of grey or blue hydrogen and are from EUR 70/MWh to EUR 130/MWh [29]. However, the market trends in natural gas and coal prices should be taken into account.

The electrolyser manufacturer estimates that the CAPEX takes 20\% of the project and $80 \%$ of the costs are allocated for OPEX. It should also be noted that approximately $95 \%$ of the OPEX is the cost of electricity. This allocation of costs is evidence that the price on green hydrogen is highly dependent on electricity prices [35].

At the current stage of the regulatory process, Germany considers two main approaches for support of green hydrogen development through OPEX (operating) and CAPEX (capital) costs [26]. 


\subsubsection{Supportive Scheme for OPEX Costs}

Green hydrogen production is based on the use of electricity from RES. However, electricity prices in Germany are growing. For instance, in the first six months of 2021, the spot price for electricity in Germany was approximately 55 EUR/MWh, much higher than in previous years with an average price 33 EUR/MWh [36]. Moreover, in June 2021, the spot electricity price reached 74.08 EUR/MWh [36], and in September 2021, the average electricity price in Germany even reached 128 EUR/MWh [37].

Considering the level of spot electricity prices in Germany, the operating costs for green hydrogen production are currently very high. To decrease operating costs, Germany adopted a surcharge payments exemption for green hydrogen under EEG 2021. This surcharge payments exemption provides a decrease in the electricity price for hydrogen production and as a result helps to reduce operating costs.

The surcharge payment exemption under EEG 2021 for electricity consumed in a green hydrogen production facility will apply from 1 January 2022 under the Ordinance on the Implementation of EEG 2021.

To rely on the surcharge payments exception, producers of green hydrogen, as final electricity consumers, and electricity suppliers for the final consumers for production of green hydrogen shall:

- Inform about this surcharge payments exception in the notification to the transmission system operator under the EEG 2021 [34]; and

- $\quad$ Prove their right to the surcharge by submitting an audit certificate as part of their notification, which should be issued by an auditor, an auditing company, a cooperative auditing association, a sworn auditor, or an auditing company that includes:

1. The maximum power consumption of the green hydrogen production equipment during one hour of operation under normal conditions,

2. The amount of electricity consumed by the green hydrogen production equipment during the calendar year in question,

3. That for the calendar year the levy for electricity consumed by the operator itself is not limited under the EEG 2021,

4. Compliance with the requirements regarding confirmation of the electricity from RES [33].

The main purpose of the surcharge payments exception under EEG 2021 is acceleration of growth of the market for hydrogen technology to reach the goals of the National Hydrogen Strategy [38].

\subsubsection{Supportive Scheme for CAPEX Costs}

According to current studies, the cost of electrolyser systems significantly affects the cost of hydrogen projects and constitutes a significant part of their CAPEX. The capital costs of water electrolysis technologies in 2020 were from $600 \mathrm{EUR} / \mathrm{kWin}$ till $2130 \mathrm{EUR} / \mathrm{kWin}$ depending on the technology [29].

For this reason, projects that could provide an initial reduction in the cost of electrolysers are actively considered and implemented in Germany. Over time, it is expected that the cost of renewable hydrogen equipment (electrolyser systems, stacks) will decrease due to increased scale and automation of production. In addition, there is a significant correlation between the cost of hydrogen production and the number of hours of use of production equipment (the more hours per year the equipment is used, the lower the cost of hydrogen production) [39].

As a supportive scheme for CAPEX costs, Germany has started the process of obtaining funding under the European initiative of IPCEI. In particular, the German state authority has selected 62 of the 230 projects submitted for funding under the IPCEI Hydrogen project. The projects, which are expected to receive funding under IPCEI, concern the production of green hydrogen (electrolyser capacity of $2 \mathrm{GW}$ ) and hydrogen infrastructure (pipelines up to $1700 \mathrm{~km}$ ), as well as the production of fuel cell systems and vehicles [40]. 
The expected project costs that will be funded by the German government total EUR 8 billion, and the involved funding will cover the investment costs of the project. However, it is also anticipated that projects and their funding under the IPCEI will trigger further investments in the sector of up to EUR 33 billion, of which EUR 20 billion is expected from private sector [26].

With the exception of special funding for the IPCEI, the following incentives for a decrease in capital costs of hydrogen projects can be considered in Germany:

- Investment aid, by means of establishment of special funding for investment in equipment for hydrogen production,

- Mechanisms to decrease risks, including state guarantees or long-term policies for hydrogen projects to decrease the projects costs [39].

\subsubsection{Other Support}

In addition to the IPCEI, Germany envisages a new contractual framework for a subsidy payments to the consumers of green hydrogen like a steel plants that would be connected with the price of a tonne of $\mathrm{CO}_{2}$ according to the EU Emission Trading System (ETS) [39]. This approach is called the "Carbon Contract for Difference" (CCfD) regime for support of the avoidance of GHG emissions by the consumer together with hydrogen [39]. Such an approach is more complex and advanced in comparison with current supportive schemes for renewables. In the EU Hydrogen Strategy, the European Commission also included a proposal with regard realization of pilot program with a CCfD scheme.

Germany considers supportive schemes not only for capital and operational costs, but also for markets and different sectors and industries before and after 2030. According to a roadmap for the presenting and development of support schemes for the hydrogen industry, the initial phase up to 2030 requires particularly strong involvement of government support measures for hydrogen supply and demand. From 2030 onward, it is expected that the gap between the cost of renewable and fossil fuel-generated hydrogen will narrow significantly, and liquid hydrogen market participants will be able to cover the gap to a large extent on their own [39].

\subsubsection{Hydrogen Infrastructure Regulation}

The regulation of green hydrogen in Germany is focused not only on hydrogen production, but also on infrastructure issues for transportation of green hydrogen. In particular, on 25 June 2021, the German Industry Act (Energiewirtschaftsgesetz, "EnWG") was amended with regard to the hydrogen network regulation [41].

It should be noted that hydrogen networks should be subject to regulation under the updated Directive 2009/73/EC ("EU Gas Directive") [42]. However, until adjustment of the EU Gas Directive, Germany decided to implement regulations for hydrogen networks for the transition period [41].

Regulation of hydrogen networks for the transitional period is based on the following approaches:

- Opt-in regulation-a regulation of hydrogen networks that shall be carried out at the choice of the respective network operator, and in case of choice of opt-in regulation,

- Vertical unbundling-when the network operator carries out activity separately from the regulation of any gas networks of the same operator [43].

Opt-In Regulation

The network operator that has a hydrogen pipeline is entitled to declare through the Federal Network Agency for electricity, gas, telecoms (Bundesnetzagentur (BNetzA)) the hydrogen pipeline for the purpose of the opt-in regulation. This option is a right of the network operator and not an obligation. However, according to the opt-in regulation, the network operator can receive the return of its costs for hydrogen networks and profit through the network tariffs paid by customers [41]. 
It should be noted that the declaration for the purpose of the opt-in regulation is possible only without a time limit, with regard to the whole hydrogen pipeline of the network operator and if the necessity of the hydrogen infrastructure is confirmed by BNetzA [41].

\section{Vertical Unbundling}

If the network operator decides to choose the opt-in regulation, the hydrogen infrastructure must comply with the following rules:

- Legal unbundling that means the independence of the network operator from the production, storage, and supply of green hydrogen;

- Accounting unbundling that means separate accounting for hydrogen pipeline operations;

- Access to the grid that means access for third parties to the grid on non-discriminatory conditions, but the network operator is entitled to deny access if connection is not possible due to operational, economic, or technical reasons [43].

The application of new regulations is possible only for the transportation of hydrogen through certain pipelines. In cases involving the transportation of blended hydrogen with natural gas, regulation for natural gas is subject to application [41].

In order to provide more certainty for investors in hydrogen projects and for implementation of the National Hydrogen Strategy on 22 September 2021, the Federal Government (Bundesregierung) adopted the Ordinance on the Costs and Charges for Access to Hydrogen Network and Amending the Incentive Regulation Ordinance ("Ordinance on the Costs for Access to Hydrogen Network"). The Ordinance on the Costs for Access to Hydrogen Network creates the basis for calculating the network costs that hydrogen network operators finance through network payments. It should be noted that this regulation of costs plays an important role for funding for IPCEI hydrogen projects [44].

Therefore, in 2021, Germany has already approved the regulations for hydrogen productions and hydrogen infrastructure to remove such barriers as uncertainty for developers and investors in hydrogen projects. At the same time, Germany plans to adjust its national hydrogen regulation in line with EU rules that will be approved later.

\subsection{Legal Regulation in Ukraine}

Ukraine does not yet have any regulation of green hydrogen. Within the framework of the Third Energy Package implementation, the electricity and natural gas markets commenced work in Ukraine. The Law on Natural Gas Market does not contain any definition or regulation of green hydrogen. At the same time, the Law on the Alternative Sources of Energy does not regulate the use of RES for green hydrogen production.

Only biohydrogen is mentioned by the Law on Alternative Types of Liquid and Gas Fuel, according to which biohydrogen is hydrogen obtained from biomass and is a type of biogas [45]. For the time being, biohydrogen is defined as a type of fuel; therefore, the legislation requires transformation to regulate hydrogen as a carrier of energy.

In the EU regulation, Ukraine was mentioned among the priority partners in the EU Hydrogen Strategy due to significant renewable energy potential. Moreover, one of the key actions under the EU Hydrogen Strategy is the promotion of cooperation on renewable electricity and hydrogen with partners in Eastern Europe, especially Ukraine [15]. At the same time, for cooperation with regard to hydrogen technology, national policies and legal regulation in Ukraine are also required. Moreover, Ukrainian legislation cannot be developed in isolation. In order to implement projects successfully with international partners, it is essential that Ukrainian legislation is harmonised with the legal framework of neighbouring and partner countries.

\subsubsection{National Hydrogen Strategy}

Ukraine has not yet approved a hydrogen strategy. However, according to the IRENA guide, approval of a hydrogen strategy precedes (1) research and development (R\&D) programmes, to have basic knowledge about technology; (2) a vision document that 
presents public and private opinion regarding the further development of hydrogen; (3) a roadmap that describes the further steps for hydrogen development; (4) strategy that is a policy document with main goals regarding the development of hydrogen technology [23].

\subsubsection{R\&D Programmes}

The most important focus for the development of hydrogen technology in Ukraine is a project launched by a Regional Gas Company (RGC, Kyiv, Ukraine) in February 2020 [46]. This project includes series of experiments to study the behaviour of hydrogen and hydrogen mixtures at different concentrations in Ukrainian gas pipelines [47]. Within this project, RGC built five sites of pipeline networks for over 180 tests and experiments [46]. It is expected that the results of this project will be used for the development of technical policies to redesign the network pipeline infrastructure [46].

The Ministry of Energy also studies the production potential of "blue", "green", and "yellow" hydrogen. It plans to use the results of these studies as a basis for a hydrogen strategy that will include a plan for developing all types of hydrogen, including its production, its use in Ukraine and export [48].

Ukrainian gas transmission system operator also has a project for exploration of the existing gas transmission system for its availability for hydrogen transportation and export to the EU [49].

According to a study on hydrogen technologies in the Energy Community, the results of R\&D projects in Ukraine can form a basis for legal regulation. Still, currently, the number of R\&D projects is very limited and requires a national and regional strategy for hydrogen technologies to be adopted [50].

At the same time, most of the mentioned R\&D programmes are connected with the development of infrastructure and logistic issues for green hydrogen supply in Germany and other EU countries. However, R\&D programmes with regard to hydrogen production are seldom subject to discussion.

$R \& D$ programmes are organised mostly by market participants and are concentrated mostly on the use of the gas pipeline for green hydrogen transportation from Ukraine to the EU.

\subsubsection{Vision Document}

The following documents on the development of green hydrogen production in Ukraine are in line with the IRENA's concept for the vision document [23], namely answering the questions "why hydrogen", "why this jurisdiction", and "why now":

Ukraine 2050 Low Emission Development Strategy developed by the Ministry of Ecology and Natural Resources of Ukraine, supported by the Government of Ukraine in July 2018 was submitted to the Secretariat of the UN Framework Convention on Climate Change and published on its website on 30 July 2018 [51]. It provides for the development of hydrogen generation, namely, incentives for hydrogen production technologies and technologies for the storage of electricity by means of green hydrogen, industrial production and use of hydrogen, promotion of hydrogen cars [51].

Green Hydrogen for a European Green Deal [10]: this initiative identifies the key role of hydrogen in achieving the European Green Deal (EGD) objectives on struggling with the problem of climate change. Ukraine has been identified as an EU neighbour with a large potential for renewable sources for green hydrogen production. Implementation of the EGD goals is limited in time, thus the document analyses the possibility of developing the hydrogen market until 2030 and reducing the cost of green hydrogen production compared to fossil-fuel hydrogen. The study establishes the possibility of ammonia production in Ukraine for the domestic market with electrolyser capacities of $1800 \mathrm{MW}$ and $8000 \mathrm{MW}$ of electrolyser capacities for the hydrogen plants for export market.

The study on hydrogen technologies in the Energy Community provides an assessment of Ukraine and its potential in the field of hydrogen. It pays special attention to R\&D and pilot projects with their impact on the development of hydrogen technologies, as well 
as the hydrogen legal and regulatory framework. The study concludes that Ukraine has potential to become a key assistant/partner of the EU Hydrogen Strategy as an exporter of hydrogen [50].

Ukraine's 2050 Green Energy Transition Concept was developed and made available for review in early 2020, after which it was further reviewed, but is still only a draft document and has not been adopted by the government as an official document. According to the final version of the concept posted on the official website of the Ministry of Environmental Protection and Natural Resources of Ukraine, increasing industrial production of hydrogen and its use is a priority in addressing the problem of the high energy consumption of national industry, and in reaching the goals of the "green" energy transition. The application of power-to-gas technologies and the creation of an industry to produce hydrogen and other renewable gases for the energy system needs are considered as an opportunity to replace the extraction of fossil energy resources and decarbonise the Ukrainian economy. Hydrogen vehicles and fuel cell vehicles are considered as decarbonising the transport sector [52].

Ukraine is also developing an Integrated Climate Change and Energy Development Plan to meet its commitments within the Energy Community. The draft Plan was announced in July 2020, but its content has not yet been made public. Given that the purpose of this document is to assess the impact of existing plans and strategies in the areas of energy security, the domestic energy markets, decarbonisation, research and innovation, it can be expected that the hydrogen industry should also be reflected in this Plan [53]. The timeline for introducing the Plan has been postponed. It is now set for 2022 according to an action plan for implementing the Annual National Program under the auspices of the NATO-Ukraine Commission for 2021 [54].

The Joint Declaration of Intent on Establishment of Energy Partnership between Germany and Ukraine is aimed at expanding cooperation between the countries in the energy sphere. The main goal of the partnership between Germany and Ukraine is to improve and create a sustainable energy infrastructure through energy efficiency and the increased application of renewables [55]. Key areas of the partnership are modernisation and decarbonisation of the electricity sector, development of RES, energy efficiency in buildings and industry, transformation of Ukrainian coal regions, and development of "green" hydrogen potential [56,57].

Thus, a clear feature to note is that vision documents on the development of the hydrogen industry in Ukraine are actively represented by international initiatives and studies. However, Ukraine needs to focus on developing internal vision documents taking into account obligations and directions previously defined in international-level documents.

\subsubsection{Roadmap}

The Ukrainian Ministry of Energy, in cooperation with the UN Economic Commission for Europe ("UNECE"), prepared the following highly important documents for hydrogen technologies development in Ukraine:

- Draft Roadmap for hydrogen production in Ukraine;

- Draft Roadmap for the use of hydrogen in Ukraine road transport;

- Draft large-scale action report in accordance with the Strategic Environmental Assessment of the Roadmap.

These documents shall become the basis for drafting a hydrogen strategy [58].

The draft Roadmap for the hydrogen production in Ukraine establishes the possibility for Ukraine to participate in German projects to provide the necessary level of hydrogen. In general, it is expected that Germany will export its technology to countries that are partners in order to import green hydrogen [59].

It should be taken into account that the draft Roadmap also establishes the potential for 537-771 GW of RES capacities in Ukraine with an average annual production of 15162273 billion $\mathrm{kWh}$ of electricity. This production volume is higher by $10-15$ times than the 
Ukrainian annual electricity consumption and can be used to produce $337-505$ billion $\mathrm{Nm}^{3}$ of green hydrogen [59].

The draft Roadmap also contains a description of the vision of Ukraine's hydrogen strategy and its main content, a budget for the strategy development of EUR 2 million, and the development duration, which is established as 24 months [59]. However, this does not comply with the decision of National Security and Defence Council (NSDC) dated 30 July 2021, according to which the Government of Ukraine should approve the relevant strategy by 31 December 2021 [60].

The draft Roadmap for hydrogen production in Ukraine envisages three phases of implementation with details on legislative developments and economic measures:

- The first phase from 2021 to 2023 deals with the analysis of the economy of Ukraine for "green transition" and start of the hydrogen economy;

- The second phase from 2024 to 2026 is dedicated to priorities for policy, hydrogen market and development of supply chain for hydrogen;

- $\quad$ The third phase from 2027 to 2029 involves development of a Smart Portfolio of

Policies together with strategic hydrogen projects, including regulatory issues and development of technologies [59].

However, these phases do not reflect estimates for Ukraine under the Green Hydrogen for a European Green Deal, according to which Ukraine shall have 8000 MW of electrolyser capacities oriented towards export markets by 2030 [10].

Meanwhile, the draft Roadmap for the use of hydrogen in road transport notes hydrogen's ability to decarbonise sectors where carbon reduction would otherwise seem impossible or very difficult (particularly private and public transport, freight logistics). The document contains a draft Roadmap for the use of hydrogen in road transport, focusing on the urban public transport segment. The draft Roadmap provides, among other things, a detailed list of transport-oriented activities that should be integrated into the overall Ukrainian Roadmap for the implementation of hydrogen technologies [61].

In addition to the drafted documents, in June 2021, the Ministry of Energy of Ukraine joined the European Clean Hydrogen Alliance to intensify their work on finding potential partners to implement projects for the production, transportation, accumulation and consumption of hydrogen [48]. This activity confirms the interests of Ukraine's state authorities in the development of hydrogen technologies.

\subsubsection{Strategy}

Ukraine's current strategy documents do not contain conditions relating to hydrogen development.

In the Energy Security Strategy of Ukraine that was approved by the Resolution No. 907-r of the Cabinet of Ministers of Ukraine dated 4 August 2021, hydrogen energy is mentioned only in the context of achieving the strategic goal on "development of scientific, technical, innovative, and educational potential of Ukraine for the needs of the energy sector" [62].

The current 2035 Energy Strategy of Ukraine "Security, Energy Efficiency, Competitiveness", approved by a resolution of the Government of Ukraine, does not include the hydrogen industry [63]. This strategy is expected to be updated in Phase 1 of the Roadmap for hydrogen production in order to reflect the latest developments on the road to a hydrogen economy [59].

The Ministry of Energy is also working to fulfil the instructions of the Cabinet of Ministers of Ukraine to develop an Energy Strategy for Ukraine until 2050 [64]. The Ministry notes that this strategy should reflect the development of a hydrogen power industry in accordance with Ukraine's status as a key partner in Europe's hydrogen economy [65].

Currently, Ukraine has no hydrogen strategy, but on 30 July 2021, the NSDC adopted a decision, enacted by the Presidential Decree of 28 August 2021 [60], pursuant to which the Government of Ukraine should approve Ukraine's hydrogen strategy by 31 December 
2021 and approve an action plan for its implementation, which should include relevant amendments to legislation.

It should be taken into account that work under this strategy has already started in Ukraine. In 2021, the Ministry of Energy with USAID assistance and the support of the World Bank commenced preparation of a Hydrogen Strategy [66]. On 11 August 2021, the first meeting of the interdepartmental working group took place. The Ministry of Energy of Ukraine noted that the strategy should be a dynamic document, taking into account the industry's novelty [67].

The main advantage of hydrogen is that it can integrate all sectors, including balancing power system modes and use in the metallurgical, chemical industries, transport, and heating. Therefore, it is important to determine the most effective methods for production of hydrogen for Ukraine, the use of resources required for its production, in particular water, during electrolysis, the possibility of scaling small projects into industrial volumes [67].

In addition to the hydrogen strategy, according to the decision of the NSDC, the Cabinet of Ministers of Ukraine should also study the issue of creating a new hydrogen product line between Ukraine and the EU and attracting investment to implement the project [60]. Despite the unrealistic timeline for the issue of a hydrogen product line, in general, the NSDC-level decision sends a signal that hydrogen issues are a national security priority for Ukraine. Therefore, Ukraine has determined terms for approval of the hydrogen strategy and work on a hydrogen strategy has begun.

\subsubsection{National Standards for Hydrogen}

Despite the absence of a hydrogen strategy and any laws regarding green hydrogen, Ukraine has made certain progress in developing the standards for hydrogen.

In order to improve the national standardisation system for devices and systems for production, storage, transportation, measurement, and use of hydrogen for power generation, the Technical Committee for Standardisation "Hydrogen Technologies" (TC 197) was established in Ukraine in June 2020 [68].

The following national standards harmonised with international standards were adopted for the first time in Ukraine [69]:

- $\quad$ DSTU ISO 14687:2021 (ISO 14687:2019, IDT) Hydrogen fuel quality. Product specification,

- $\quad$ DSTU ISO/TR 15916:2021 (ISO/TR 15916:2015, IDT) Basic considerations for the safety of hydrogen systems,

- $\quad$ DSTU ISO 22734:2021 (ISO 22734:2019, IDT) Hydrogen generators using water electrolysis. Industrial, commercial, and residential applications.

These standards entered into force from 1 May 2021.

However, this is a small part of the required standards. According to the estimates of the Institute of Renewable Energy, it will be necessary to adapt 67 European standards to the legislation of Ukraine [70].

\subsubsection{Pilot Projects}

Notwithstanding the absence of a hydrogen strategy and any regulation, Ukraine has a pipeline of pilot projects for hydrogen production. The following projects for hydrogen production are at the development stage:

- Danube hydrogen valley project is a pilot project to create an energy cluster in the south of Ukraine (Odesa region). According to the released information, the project envisages five stages of development. Documentation required to commence construction of the first stage (50 MW PV and 50 MW electrolysers) has already been developed. Permits for the construction of 43 MW PV have been obtained. The project's total capacity is expected to be $5 \mathrm{GW}$ of renewable energy sources (WP and PV) and $3 \mathrm{GW}$ of electrolysers. The project's total cost is EUR 14 billion, of which EUR 100 million are required to implement the first stage. The project is expected to be implemented by 2025 [71]. 
- $\quad$ Transcarpathian green $\mathrm{H} 2$ project involves construction of a "green" hydrogen production plant based on renewable electricity (100 MW PV, 30-35 MW electrolysers, 30 MW electricity storages). The total investment required for the project implementation is EUR 130 million. The project is promising also because of the infrastructure opportunities-pipeline, road, and rail transport are available for the project [71].

- Green Hydrogen Industrial Cluster is a project of DTEK LLC, involving a public-private partnership with German and Ukrainian industrial stakeholders. The project location is in the Nikopolskiy basin in south-eastern Ukraine. The expected pilot project capacity of electrolyser is $8.5 \mathrm{MW}$ with potential of $200 \mathrm{MW}$. Local consumption and export of the produced hydrogen are seen as possible demand components of the project [71].

- A project in the Rivne region is being developed by the MCL group of companies. It is planned to produce electricity with $72 \mathrm{MW}$ wind power plants. The generated hydrogen will be used for ammonia production. The project is at the feasibility study stage, and a financial partner is being sought [72].

- A project by the Eco-Optima group of companies focuses on construction of a plant to produce green hydrogen with a capacity of $100 \mathrm{MW}$. It is estimated that the project will cost EUR 300 million, and it has been submitted for a tender, which was announced in July 2021 by the H2 Global fund [73].

The main peculiarity of the pilot hydrogen projects in Ukraine is that most of projects are developing together with renewable generation capacities. One of the possible reasons for this approach is a lack of the guarantee of origin scheme in Ukraine, while the other is the dependence of the support system for green hydrogen production on the source of electricity generation, since new RES capacities will be used for hydrogen production with the support system, contributing more to the decarbonisation goal. At the same time, such projects are more complicated and additional investments for renewable capacities are required due to construction of wind or solar plants together with electrolysers.

Alongside pilot projects for hydrogen production, Ukrainian companies are also developing cooperation with EU companies. For instance, a joint project of cooperation between the gas companies of Ukraine and Germany was established on 22 August 2021 by signing a Memorandum of Understanding between Ukraine's largest gas company PJSC "Naftogaz of Ukraine" and the German gas trader RWE Supply \& Trading. According to the Memorandum, the companies agreed to analyse the possibilities of cooperation to create a complete value chain for green hydrogen produced in Ukraine. The priority of companies is the development of projects for hydrogen production and storage in Ukraine and its export to Germany [74].

According to the Hydrogen Project Visualisation Platform developed by the ENTSO-G, four infrastructure projects are indicated on the territory of Ukraine. The projects in Kyiv region (TSO UA) and in Lutsk (RGC) are dedicated to the study of the adaptability of existing gas networks to transport hydrogen and the re-purposing of existing infrastructure, the main topic of the project in Kyiv (TSO UA) is an examination of adaptability of gas storage infrastructure for hydrogen storage. The project is located in the south of Ukraine, around the Kakhovka reservoir. It is dedicated to the development of a hybrid park of wind and solar generation with subsequent conversion of energy into "green" hydrogen ("green" ammonia) [49].

For the implementation of the current pilot projects, the current regulatory framework and necessary approvals/permits for hydrogen production shall be taken into account. Production of $1 \mathrm{~kg}$ of hydrogen via electrolysis requires $8.92 \mathrm{~L}$ of water [75]. However, according to Article 48 of the Water Code of Ukraine, the use of water more than 5 cubic metres per day qualifies as special water use, i.e., is subject to a fee and a permit. Thus, it is likely that the realisation of hydrogen projects producing green hydrogen will also require a special water use permit.

Hydrogen belongs to the list of individual hazardous substances according to the Government resolution No. 956 “On Identification and Declaration of Safety of Objects 
of the Increased Danger" dated 11 July 2002, thus procedures for identifying high-risk objects under the Law "On Extremely Dangerous Objects" should be considered. At the same time, production of hazardous substances is high-risk work that can be performed only based on a permit under the Government resolution No. 1107 dated 26 October 2011 “On Approval of Procedure for Issuing Permits for Performance of Work of Increased Risk and for Operating (Using) Machines, Mechanisms and Equipment of Increased Risk". Considering the physical features of hydrogen as an explosive material, a permit for highrisk work will probably also be required. However, these permits apply for all projects in the energy sector and do not include rules for the green hydrogen production.

Moreover, taking into account the specifics of the pilot projects, developers should consider the list of objects and activities, for which the environmental impact assessment procedure under the Law "On Environmental Impact Assessment" (the list includes chemical production; pipelines for gas, chemicals; chemical storage facilities, etc.) is required.

Alongside permits, the implementation of pilot hydrogen projects in Ukraine is not possible without financing. Taking into account the high cost of green hydrogen and a lack of consumers, the realisation of projects at the current stage is possible only with funding. It should be noted that in October 2021, Germany announced a funding guideline for providing financial support to international hydrogen projects to boost the international hydrogen market in compliance with the National Hydrogen Strategy. This funding can cover $25-45 \%$ of eligible costs for each project with a maximum amount of EUR 15 million per project and per applicant. However, the applicant for this funding should have a headquarters in the EU or a permanent establishment in Germany [76], which can serve as an obstacle for Ukrainian projects.

\subsubsection{Guarantee of Origin Schemes}

In the development of the entire green hydrogen industry, special attention is paid to certification issues. It is important that the consumer, regardless of residence, can confirm that the purchased green hydrogen meets the needs and goals requiring the investment of additional funds. Since market development in Ukraine is focused on European partners and it is European countries (namely Germany) that are potentially considered as the main sales market for "green" hydrogen produced in Ukraine. It is logical that the system for confirming the origin of such hydrogen should correspond to the European model. This approach can have an additional positive contribution to the development of the hydrogen sphere, since it will be understandable and cost-effective for European market participants.

It should be noted that the initiative on the establishment of a regional certification system, allowing for trade among Contracting Parties of the Energy Community, has been also announced earlier [77].

Regarding the current regulation in Ukraine, there is a Resolution of the Government of Ukraine "On Approval of the Procedure for Issuance, Use and Termination of the Guarantee Origin of Electricity for Business Entities Producing Electricity from Alternative Energy Sources" No. 771 dated 24 July 2013 [78], which is valid, but which has never been applied.

The mechanisms to introduce a guarantee of the origin of energy in Ukraine in accordance with the EU standards were discussed by the State Agency on Energy Efficiency of Ukraine with the Association of Issuing Bodies. To increase transparency, security of data storage and the reliability of relevant systems, and to prevent double issuance of guarantees of origin, the possibility of developing such a system on blockchain technology and/or using the software of the Energy Community is being considered [79].

Therefore, Ukraine has only commenced work under the hydrogen strategy but has no regulation for green hydrogen production and infrastructure as Germany. At the same time, in addition to regulatory issues, Ukraine has technical barriers for production of green hydrogen connected with the lack of flexibility of the existing energy system. 


\subsection{Improving the Flexibility of the Ukrainian Power System}

The main resource for green hydrogen production is electricity from renewables. According to disclosed information about preferable renewable resources for over $54 \%$ of hydrogen projects announced in the EU, the main renewable sources for most of these projects are the following:

- $\quad 39 \%$ of hydrogen projects with capacity $77 \%$ prefer wind energy;

- $\quad 18 \%$ of hydrogen projects with capacity $14 \%$ prefer solar energy;

- $\quad 22 \%$ of hydrogen projects with capacity $7 \%$ prefer solar and wind [29].

Ukraine has very good natural conditions for increasing renewable electricity production. Pursuant to the atlas of energy potential of RES, Ukraine has the following potential of renewables for hydrogen production [5] as determined in Table 2:

Table 2. Energy potential of RES in Ukraine [5].

\begin{tabular}{ccc}
\hline Scenario & Technology & Capacity, GW \\
\hline Basic & & 537 \\
\hline & Onshore Wind & 320 \\
\hline & Offshore Wind & 146 \\
\hline Optimistic & Solar & 71 \\
\hline & & 771 \\
\hline & Onshore Wind & 438 \\
\hline & Offshore Wind & 250 \\
\hline & Solar & 83 \\
\hline
\end{tabular}

Taking into account the potential of renewable energy resources, Ukraine's general potential for hydrogen production is estimated at an amount of 505,133 million cubic meters [5].

The significant potential of offshore wind in Ukraine is also confirmed by the World Bank's analysis of the Black Sea potential. According to this research, Ukraine has $251 \mathrm{GW}$ total capacity of offshore wind that is more than the average capacity of Bulgaria, Romania and Turkey under Table 3 [80].

Table 3. Offshore wind potential in the Black Sea [80].

\begin{tabular}{cccc}
\hline Countries & $\begin{array}{c}\text { Fixed Wind } \\
\text { Turbines, GW }\end{array}$ & $\begin{array}{c}\text { Floating Wind } \\
\text { Turbines, GW }\end{array}$ & Total Capacity, GW \\
\hline Ukraine & 183 & 68 & 251 \\
\hline Bulgaria & 2 & 24 & 26 \\
\hline Romania & 22 & 54 & 76 \\
\hline Turkey & 12 & 63 & 75 \\
\hline Total & 269 & 166 & 435 \\
\hline
\end{tabular}

Due to high feed-in tariffs, Ukraine experienced significant growth in renewable energy capacities during the last several years. In October 2021, the installed capacity of renewables in Ukraine was 7954.60 MW, which consists of 6194 MW of solar power plants, $1529 \mathrm{MW}$ of wind power plants, and $232 \mathrm{MW}$ of biofuel plants, according to information from the TSO [4]. However, the solar power plant share is four times greater than wind power plants, leading to an unbalancing of the energy system. The share of renewables is 14.18 percent in the energy system of Ukraine with an installed capacity $56,067.40 \mathrm{MW}$, where above 50 percent electricity is generated by nuclear power plants, and above 25 percent by coal power plants. 
Considering the prevailing capacities of the nuclear and coal generation and rapid growth of renewables, Ukraine's energy system lacks balancing capacities. For this reason, the future growth of renewables in Ukraine is not possible without improvement of energy system flexibility. However, with the development of green hydrogen projects in Ukraine, it is possible to improve the energy system's flexibility through potential advantages of green hydrogen production [23].

The production of green hydrogen can be useful for the integration of an increased share of renewables in the Ukrainian energy system and improving the flexibility of it in the following ways:

- $\quad$ Participating in the electricity market for the balancing of renewables;

- $\quad$ Reducing renewables curtailments.

\subsubsection{Balancing of Renewables on the Electricity Market}

According to a report on compliance assessment (sufficiency) of generating facilities prepared by NPC Ukrenergo (TSO) for 2020, to ensure the integration of renewables in the forecast volumes, it is important to construct at least $1 \mathrm{GW}$ of highly maneuverable capacities in the shortest possible time that will be able to start and stop power and time of commissioning (full activation) at least four times per day from the resting state not more than $15 \mathrm{~min}$ from the moment of receipt of the corresponding command from the TSO [81].

A study of electrolyser flexibility confirms that electrolysers for green hydrogen production can be electricity market participants and provide some services in the market. For instance, if the electrolyser works at $80 \%$ of its capacity for green hydrogen production, $20 \%$ of its capacity can be used for regulation and load shedding on the electricity market [82].

The participation of electrolysers in different electricity market segments depends on the speed of their response to certain bids, but the study confirms that the quickest response of the electrolyser can be within $1 \mathrm{~min}$ [82]. Moreover, testing of electrolysers by the Hydrogenics Corporation confirmed the possibility of their use for frequency regulation, balancing of supply and stabilisation of the distribution grid [83].

Thus, the electrolysers can be used not only to produce green hydrogen but also to balance the Ukrainian energy system and frequency regulation.

\subsubsection{Reduction of Renewables Curtailments}

The main problems of solar and wind generation are over-generation in some periods and intermittency in generation depending on weather conditions. Due to the rapid growth of renewables in Ukraine, the curtailment of renewables became a solution for overgeneration. In particular, after use of all balancing possibilities in Ukraine, the dispatcher of NPC Ukrenergo (TSO) has made the following commands for renewables curtailments:

- 20 times in 2020 for RES capacities from 212 to $1656 \mathrm{MW}$;

- 2 times in 2019 for RES capacities 250-300 MW [81].

Curtailments for renewables producers under the feed-in tariff are subject to compensation under the feed-in tariff. However, this approach is very expensive for the state and not effective, taking into account the possibility of using the curtailed renewable electricity for production of green hydrogen.

To reduce the curtailments of renewables in Ukraine, it is required to have at least $2 \mathrm{GW}$ of highly maneuverable capacities in line with the report on compliance assessment (sufficiency) of the generating facilities of NPC Ukrenergo (TSO) [81]. High maneuverable capacities can be constructed in Ukraine based on a special government procedure. The perspectives for their construction in Ukraine are not clear yet.

However, it is possible to decrease the curtailments of renewables with the use of electrolysers for green hydrogen production. According to the results of the "Wind-toHydrogen Energy Pilot Project," the possibility was confirmed of mitigating wind intermittency by electrolyser. It was found that the electrolyser can provide a rapid response in the system to mitigate variability and intermittency of wind [84]. 
For instance, the island of Orkney in the UK produces green hydrogen by means of the use of the surplus renewable energy instead of curtailment. This approach was introduced in the Orkney Hydrogen Strategy [85] and implemented in the BIG HIT project that shall absorb curtailed renewable energy [86].

The possibility of using power-to-gas installations for hydrogen production is considered as a solution for use of the surplus renewable electricity due to low demand and network restrictions. For instance, in such countries as Denmark, Portugal, the Netherlands and Spain, the renewables installed capacities by 2030 will require additional flexibility that is possible to reach through hydrogen installations [87].

Therefore, surplus renewable electricity can be used for hydrogen production instead of its curtailment, and the hydrogen installation can improve the flexibility of the energy system with large installed capacities of renewables. However, all these options are rather technical and current regulation of the electricity market of Ukraine does not allow for the use of electrolysers for the flexibility improvement of the energy system.

Alongside a solution to the problems connected with the flexibility of the Ukrainian energy system, the production of green hydrogen in Ukraine could significantly impact German plans with regard to energy transition.

\subsection{Possibility of Energy Transition for GERMANY with the Use of Green Hydrogen}

Germany plans to achieve climate-neutrality by 2045 and green hydrogen plays a key role in achieving this goal.

It also shall be noted that initially Germany planned the achievement of climate neutrality by 2050. However, following a 2021 ruling by Germany's highest court, Germany decided to shift to a climate-neutral scenario by 2045 [88]. This decision led to an acceleration of all processes and the hydrogen plays important role in this activity.

In the German energy sector, it is expected that by the end of the 2020s, heat and/or power plants will use hydrogen. Moreover, after 2040, hydrogen shall be used instead of natural gas. In the industry sector, the German steel industry will also work primarily with hydrogen [89].

To reach climate-neutrality, there are three levels for the acceleration of this result in Germany. On the first level, Germany plans to improve energy efficiency and reduce energy demand. The second level of acceleration is based on renewable power generation and electrification. It is expected that by 2045, the share of RES in the energy system of Germany will reach $100 \%$ and electricity demands will be covered in the following way:

- $\quad 89 \%$ from renewable energy, including hydropower and biomass;

- $\quad 6 \%$ from power plants with the use of green hydrogen;

- $\quad 5 \%$ from storage or import [89].

It shall be noted that, in addition to the use of green hydrogen instead of natural gas, Germany also considers the possibility of making the power system more flexible with the help of energy consumption, including electrolysers [89].

On the third level, Germany considers hydrogen as both fuel and feedstock to accelerate the energy transition. It is expected that in 2045, Germany will need 265 TWh of hydrogen, only $36 \%$ of which will be produced in Germany. This means that Germany needs to import most of the required volume of green hydrogen from other countries [89].

Taking into account that by 2045 Germany will be able to produce only $36 \%$ of green hydrogen from domestic demand, an energy partnership with Ukraine can be a solution for the import of green hydrogen. At the same time, to realise the ambitions of the Energy Partnership between Germany and Ukraine, it is important to remove all obstacles to the realisation of hydrogen projects in Ukraine.

\section{Discussion}

As the hydrogen industry is in its infancy, there are a number of challenges and issues for discussion that are common to the global market, including the further development of the German-Ukrainian energy partnership. 
In order to understand the perspectives for the realisation of hydrogen projects in Ukraine and identify key barriers, the Ukrainian Wind Energy Association (UWEA) conducted a survey in September 2021 addressing green hydrogen production. This survey was performed to assess the opinions of main market participants for the purposes of this article.

The survey was performed in the form of an online questionnaire that was sent to all members of the UWEA. The questions to the respondents concerned the following main issues:

- The impact of green hydrogen development on increasing of renewable capacities;

- Perspectives of green hydrogen projects performance by the respondents;

- Potential of green hydrogen projects to become rationale for the implementation of

RES projects under market conditions;

- Development of regulation for implementation of hydrogen project in Ukraine.

In order to clarify the participants' view of the German-Ukrainian Energy Partnership, the questionnaire included a question on the possible consequences of cooperation with Germany for Ukrainian business entities in the framework of the energy partnership. The survey featured nine companies, including the main wind energy producers, a wind turbine producer, and consulting companies.

Almost all participants agree that green hydrogen development is a prospective business that can increase renewable capacities in Ukraine. The reasons for production of green hydrogen by the opinion of each company are different. Some companies consider green hydrogen as a priority area for innovation, others believe that this direction significantly increases the demand for "green" energy in Ukraine in relation to the "green transition" and increases the need for wind energy to produce hydrogen for consumption in Ukraine and abroad.

It should be taken into account that more than half of the companies participating in the survey plan to implement green hydrogen projects. At the same time, members of the UWEA mentioned obstacles to increasing renewables for the Ukrainian hydrogen projects. Among the main barriers to the increase in renewable capacities for hydrogen production, the participants of the survey mentioned the following:

- Legal and political framework;

- Lack of corporate renewables power purchase agreements (PPAs) and auctions for renewables;

- Lack of technical regulations for hydrogen, transmission fees and regulation for customs regulations;

- $\quad$ Lack of proper planning of green hydrogen development by the state;

- Uncertainty regarding consumer and prices;

- $\quad$ Lack of guarantees of origin system;

- Lack of strategy and infrastructure.

At the same time, not all companies consider hydrogen projects a rationale for implementation of renewable projects under market conditions. Only three companies from nine confirmed this possibility. The main reasons for their opinion include high prices for green hydrogen and concerns regarding the sufficiency of a market-based approach. For this reason, most of the participants in the survey mentioned the importance of a supportive scheme for green hydrogen production.

According to the opinion of most participants of the survey, the following key amendments to the laws of Ukraine are required: corporate PPAs, implementation of a guarantee of origin system, main rules for the production and transportation of hydrogen, stimulation schemes for green hydrogen and hydrogen strategy.

As to the consequences of cooperation with Germany within the framework of the energy partnership in the field of "green" hydrogen, five Ukrainian companies believe in positive consequences of this energy partnership. At the same time, some companies have 
concerns due to uncertainty about this cooperation connected with the unclear conditions for Ukrainian companies.

Among the answers in the UWEA's survey, one participant raised the hydrogen "chicken and egg" problem in terms of the high cost of "green" hydrogen, which holds back demand for the product. At the same time, low demand is a disincentive to invest in the industry. According to a study, the cost of "green" hydrogen is USD 4-6 per kg compared to the USD 1-2 per $\mathrm{kg}$ for fossil fuels-based hydrogen. The chicken and egg problem could be solved when cost parity of "green" and fuels-based hydrogen is achieved, and a competitive market could be established [90].

In addition to the cost of "green" hydrogen itself, the problem is aggravated by a lack of regulation, data on the technologies and "green" hydrogen transactions, as well as on the assessment of the benefits that can be acquired by switching to "green" hydrogen.

Experts suggest the following tools to address this problem:

- $\quad$ Regulatory policy should involve the hydrogen sector while developing documents on the regulation of broad energy issues: energy and sustainability policies as well as policies on social and economic development, etc. [23];

- $\quad$ Supportive policies for the hydrogen industry, which should initially help to overcome the problem of increased investment risk and ensure market launch, but which should change as technology develops, their costs decrease, and the hydrogen market evolves, right up to the transition of the hydrogen sector to full market relations without government support. The following schemes are currently considered: (i) auctions for carbon contracts for differences (CCfDs), which are subject to an emissions trading system (ETS) and provide for selected industries, provided they use "green" hydrogen, an opportunity to receive a stable income granted by the state of the difference between the strike price offered by the bidder at the auction (in case of victory) and the market price of emission allowances; (ii) auction without the need for physical exchange of "green hydrogen", where an auction involving a specially established intermediary, on the one hand, concludes a purchase agreement with "green" hydrogen producers under the lowest auction price, and on the other hand, concludes an agreement with "green" hydrogen consumers at the highest auction price. The difference in contract prices imposed on the intermediary can be compensated by a carbon tax and/or ETS revenues [90].

Alongside regulatory issues and the high price of green hydrogen, one of the most important issues for German and Ukrainian energy partnership in green hydrogen production is the infrastructure for transportation of green hydrogen from Ukraine to Germany. At the current stage, Ukrainian gas infrastructure can only transport green hydrogen blended with natural gas. However, in order to achieve climate neutrality, Germany needs to have pure green hydrogen.

Taking into account technical restrictions for the supply of green hydrogen through existing infrastructure, in September 2021, four leading gas infrastructure companies announced plans to join forces to build a hydrogen backbone through Central Europefrom Ukraine to Germany through several countries (Slovakia, the Czech Republic) — the Central European Hydrogen Corridor [91]. The participating companies of the Central European Hydrogen Corridor are EUSTREAM (Slovakia's GTS operator), Gas Transmission System Operator of Ukraine, NET4GAS (Czech GTS operator) and OGE (Germany's leading GTS operator).

Notwithstanding the existing uncertainty regarding green hydrogen transportation, the supply of renewable electricity from Ukraine to Germany was not subject to discussion. On the current stage of development of Ukrainian and German energy sectors the following barriers for such option exist:

- Ukraine cannot supply electricity to the EU (except Burshtyn Island) before integration with ENTSO-E that is expected in 2023; 
- Ukraine does not have a guarantee of origin scheme for renewable electricity and without this scheme the supply of electricity in Germany for the purpose of green hydrogen production will not be possible;

- Germany provides the supportive scheme for hydrogen production with the use of at least 85 percent of electricity produced in Germany. For this reason, the use of the Ukrainian renewable electricity would be possible only without a supportive scheme; - All renewable projects in Ukraine are realised under the feed-in tariff that can be higher than the wholesale market prices in certain periods. For this reason, it is important also to ensure the realisation of renewable projects in Ukraine under the market-based approach.

Therefore, the realisation of green hydrogen projects in Ukraine depends on the removal of key obstacles such as the lack of legal regulation, and infrastructure issues for the transportation of hydrogen. At the same time, developers and investors would also like to have clarity with regard to consumers of green hydrogen, which is also unclear at the current stage of technology development.

\section{Conclusions}

Ukraine and Germany have a lot of preconditions for the development of an energy partnership and energy transition. Ukraine has high potential for renewables that could be a precondition for green hydrogen production not only for its own needs, but also to supply to Germany. In this way, Germany can cover its internal demand for green hydrogen and reach its goals regarding climate neutrality. At the same time, to realise these possibilities, it is important to remove the following barriers:

Significant difference in the level of regulatory development. The development and adoption of a regulatory base for hydrogen in Ukraine is much slower than in Germany. Ukraine has just started work on a Hydrogen Strategy, while Germany has already adopted not only a strategy but also the regulations for hydrogen production with incentives and hydrogen grids. At the same time, due to a lack of regulation for hydrogen projects in Ukraine, investors cannot assess perspectives for realization of such projects at the current stage. The announced pilot projects in Ukraine could be realised in case of support from the state or via special funding for such projects. However, on market-based conditions, the realization of hydrogen projects in Ukraine is not possible.

Further recommendations to remove the barrier: accelerating development of the regulatory framework in Ukraine and its harmonisation with Germany while considering the already existing norms and obligations of Ukraine in the field. Among which, the priority areas are (i) safety standards for the use of hydrogen in various technical processes, (ii) regulation of the permissive framework for the use of hydrogen in business activities, (iii) laying the foundations for the green hydrogen market (guarantees of the origin of electricity and hydrogen, supportive system for the implementation of green hydrogen projects). Availability of joint German-Ukrainian green hydrogen projects at the local level can also contribute to the elimination of this barrier.

Uncertainty regarding possible technical restrictions. Logistic issues for the transportation of green hydrogen from Ukraine to Germany are still subject to discussion. The Gas TSO and other market participants consider different approaches to these issues. Taking into account that the gas pipeline requires modernisation for the transportation of green hydrogen, the construction of a separate hydrogen pipeline is under consideration as a possible solution. Alongside transportation issues, the production of hydrogen requires the use of water resources and special permits for this activity, but these issues are not analysed enough yet.

Further recommendations to remove the barrier: launch and intensify scientific and technical studies on the impact of hydrogen on the potential existing logistical infrastructure (gas pipeline), both in Germany and Ukraine, the sufficiency of other natural resources (water) for production purposes, and feasibility studies for the construction of a separate pipeline between Ukraine and Germany. 
Lack of flexibility of the Ukrainian energy system for RES deployment. To produce green hydrogen, Ukraine needs to increase installed capacities of renewables. However, the realisation of renewable projects can be restricted due to a lack of balancing capacities in Ukraine. Electrolyser capacities can be considered as an option for improvement of energy system flexibility, but this approach is not yet considered.

Further recommendations to remove the barrier: consider and analyse possible solutions to improve the flexibility of the Ukrainian energy system by means of the electrolysers for hydrogen production.

Uncertainty about availability of consumers of the green hydrogen. The cost of green hydrogen is higher than for fossil fuels and, currently, the demand for green hydrogen is not as high as expected to be in 2030. For this reason, one of the main concerns of investors in hydrogen projects is the possibility of finding a consumer for green hydrogen. Although, market trends in fossil fuels costs need to be taken into account.

Further recommendations to remove the barrier: Analysis of the production structure in Ukraine and Germany, development of clear scenarios for green hydrogen use, a clear justification of the benefits of its use, and based on the above, data identification of the list of potential green hydrogen consumers (groups).

Author Contributions: Conceptualisation, M.H.; writing—original draft preparation, M.H. and N.H.; writing-review and editing, M.H. and N.H. All authors have read and agreed to the published version of the manuscript.

Funding: This research was funded by Sayenko Kharenko law firm.

Institutional Review Board Statement: Not applicable.

Data Availability Statement: Any data presented in this paper may be obtained by contacting the authors.

Acknowledgments: In this section, you can acknowledge any support given which is not covered by the author contribution or funding sections. This may include administrative and technical support, or donations in kind (e.g., materials used for experiments).

Conflicts of Interest: The authors declare no conflict of interest.

\section{References}

1. Міністерство Енергетики України. Співпраця України і НімеччиниПродовжиться за П’ятьма ПріоритетнимиНапрямками вЕнергетиці. Available online: http://mpe.kmu.gov.ua/minugol/control/uk/publish/article?art_id=245532781\&cat_id=35109 (accessed on 20 October 2021).

2. Mind; Рєпкін, О. «Зелений» Водень для України: якҮрятуватиПрироду та ГТС. 5 November 2019. Available online: https: //mind.ua/openmind/20204093-zelenij-voden-dlya-ukrayini-yak-uryatuvati-prirodu-ta-gts (accessed on 20 October 2021).

3. Deutsche Energie-Agentur GmbH (dena). Stakeholder Survey. German Business Perspective on Hydrogen Projects in Ukraine in the Context of the German-Ukrainian Energy Partnership. June 2021. Available online: https:/ / www.energypartnership-ukraine. org/fileadmin/user_upload/ukraine/media_elements/20210608_Hydrogen_Survey_final.pdf (accessed on 20 October 2021).

4. Ukrenergo National Power Company. Installed Capacity of the IPS of Ukraine Values as of 10/2021. Available online: https: / / ua.energy/installed-capacity-of-the-ips-of-ukraine/ (accessed on 11 November 2021).

5. UkrEneregoExport. Атлас Енергетичного ПотенціалуВідновлюваних Джерел Енергії України. Available online: https: //www.ukrenergoexport.com/en/node/353 (accessed on 20 October 2021).

6. Hydrogen Europe Clean Hydrogen Monitor 2020. Available online: https://reglobal.co/wp-content/uploads/2021/01/Clean-H ydrogen-Monitor-2020.pdf (accessed on 20 October 2021).

7. Federal Ministry for Economic Affairs and Energy. The National Hydrogen Strategy. Available online: https://www.bm wi.de/Redaktion/EN/Publikationen/Energie/the-national-hydrogen-strategy.pdf?_blob=publicationFile\&v=6 (accessed on 20 October 2021).

8. REUTERS. Renewables Meet 46.3\% of Germany's 2020 Power Consumption, up 3.8 pts. 14 December 2020. Available online: https: / / www.reuters.com/article/germany-power-renewables-idUKKBN28O1AH (accessed on 20 October 2021).

9. Tagesschau. Wasserstoff Statt Erdgas aus der Pipeline? 2 July 2021. Available online: https://www.tagesschau.de/faktenfinder/ wasserstoff-pipeline-ukraine-101.html?fbclid=IwAR1mUwXP5ouI1cwgqan4-ptgzumYit5oaiwc9ke3LWLMtrYj3gtw5ER_sWA (accessed on 20 October 2021). 
10. van Wijk, A.; Chatzimarkakis, J. Green Hydrogen for a European Green Deal A $2 \times 40$ GW Initiative. 2020. Available online: https://dii-desertenergy.org/wp-content/uploads/2020/04/2020-04-01_Dii_Hydrogen_Studie2020_v13_SP.pdf (accessed on 20 October 2021).

11. Hydrogen Europe. Green Hydrogen Investment and Support Report. Hydrogen Europe's Input for a Post COVID-19 Recovery Plan. Available online: http:/ / profadvanwijk.com/wp-content/uploads/2020/05/Hydrogen-Europe_Green-Hydrogen-Reco very-Report_final.pdf (accessed on 1 November 2021).

12. European Commission. Speech by President von der Leyen to the Hydrogen Council. 19.01.2021, Brussel. Available online: https:/ / ec.europa.eu/commission/presscorner/detail/en/SPEECH_21_158 (accessed on 11 November 2021).

13. Communication from the Commission to the European Parliament, the Council, the European Economic and Social Committee and the Committee of the Regions. Updating the 2020 New Industrial Strategy: Building a stronger Single Market for Europe's recovery. Available online: https:/ / ec.europa.eu/info/sites/default/files/communication-new-industrial-strategy.pdf (accessed on 23 October 2021).

14. EUR-Lex. Access to European Union Law. Communication from the Commission to the European Parliament, the European Council, the Council, the European Economic and Social Committee and the Committee of the Regions. Europe's moment: Repair and Prepare for the Next Generation. Available online: https:/ / eur-lex.europa.eu/legal-content/EN/TXT/?qid=159073252101 3\&uri=COM:2020:456:FIN (accessed on 23 October 2021).

15. Communication from the Commission to the European Parliament, the Council, the European Economic and Social Committee and the Committee of the Regions. A Hydrogen Strategy for a Climate-Neutral Europe. Available online: https://ec.europa.eu/e nergy/sites/ener/files/hydrogen_strategy.pdf (accessed on 23 October 2021).

16. EUR-Lex. Access to European Union Law. Consolidated Text: Directive 2014/94/EU of the European Parliament and of the Council of 22 October 2014 on the Deployment of Alternative Fuels Infrastructure. Available online: https:/ / eur-lex.europa.eu/ legal-content/EN/TXT/?uri=CELEX\%3A02014L0094-20200524 (accessed on 25 October 2021).

17. EUR-Lex. Access to European Union Law. Consolidated Text: Directive (EU) 2018/2001 of the European Parliament and of the Council of 11 December 2018 on the Promotion of the Use of Energy from Renewable Sources. Available online: https: / / eur-lex.europa.eu/legal-content/EN/TXT/?uri=CELEX\%3A02018L2001-20181221 (accessed on 25 October 2021).

18. HyLAW Deliverable 4.4 EU Regulations and Directives Which Impact the Deployment of FCH Technologies. Available online: https: / / www.hylaw.eu/sites/default/files/2019-02/D4.4\%20-\%20EU\%20regulations\%20and\%20directives\%20which\% 20impact $\% 20$ the\%20deployment\%20of\%20FCH\%20technologies_0.pdf (accessed on 23 October 2021).

19. EUR-Lex. Access to European Union Law. Directive 2012/18/EU of the European Parliament and of the Council of 4 July 2012 on the Control of Major-Accident Hazards Involving Dangerous Substances, Amending and Subsequently Repealing Council Directive 96/82/EC. Available online: https:/ / eur-lex.europa.eu/legal-content/EN/TXT/?uri=celex\%3A32012L0018 (accessed on 23 October 2021).

20. EUR-Lex. Access to European Union Law. Directive 2014/34/EU of the European Parliament and of the Council of 26 February 2014 on the Harmonisation of the Laws of the MEMBER States Relating to Equipment and Protective Systems Intended for Use in Potentially Explosive Atmospheres (Recast). Available online: https:/ / eur-lex.europa.eu/legal-content/en/TXT/?uri=CELEX: 32014 L0034 (accessed on 23 October 2021).

21. EUR-Lex. Access to European Union Law. Consolidated Text: Directive 2010/75/EU of the European Parliament and of the Council of 24 November 2010 on Industrial Emissions (Integrated Pollution Prevention and Control). Available online: https: / / eur-lex.europa.eu/legal-content/EN/TXT/?uri=CELEX\%3A02010L0075-20110106 (accessed on 25 October 2021).

22. Florence School of Regulation. Hydrogen Regulation under Time Pressure. Available online: https://fsr.eui.eu/hydrogen-regula tion-under-time-pressure/ (accessed on 23 October 2021).

23. IRENA. Green Hydrogen Supply: A Guide to Policy Making; International Renewable Energy Agency: Abu Dhabi, United Arab Emirates, 2021. Available online: https://www.irena.org/- / media/Files/IRENA/Agency /Publication/2020/Nov/IRENA_ Green_hydrogen_policy_2020.pdf (accessed on 23 October 2021).

24. Deutsche Welle. Germany and Hydrogen—€9 Billion to Spend as Strategy Is Revealed. Available online: https://www.dw.com /en/germany-and-hydrogen-9-billion-to-spend-as-strategy-is-revealed/a-53719746 (accessed on 23 October 2021).

25. Bundesnetzagentur. Regulation of Hydrogen Networks. Results of the Market Consultation. Available online: https: //www.bundesnetzagentur.de/SharedDocs/Downloads/DE/Sachgebiete/Energie/Unternehmen_Institutionen/Netzentwi cklungUndSmartGrid/Wasserstoff/Konsultationsbericht_EN.pdf?_blob=publicationFile\&v=2 (accessed on 23 October 2021).

26. Insitut Montaigne. Green Deal Reloaded-Clean Hydrogen: The Way Forward Is Together. Available online: https:// www.institutmontaigne.org/en/blog/green-deal-reloaded-clean-hydrogen-way-forward-together\#faq13287_1 (accessed on 23 October 2021).

27. Stratas Advisors. Well-Functioning and Unified Certification Market as a Prerequisite for Development of Hydrogen Economies in Europe. Available online: https://stratasadvisors.com/Insights/2021/03152021-Hydrogen-Certification (accessed on 23 October 2021).

28. CertifHy-The First European Guarantee of Origin for Green \& Low Carbon Hydrogen. Available online: https:/ / www.certifhy .eu/images/media/files/CertifHy_Leaflet_final-compressed.pdf (accessed on 23 October 2021). 
29. Market State and Trends in Renewable and Low-Carbon Gases in Europe. A Gas for Climate Report. December 2020. Available online: https: / / gasforclimate2050.eu/wp-content/uploads/2020/12/Gas-for-Climate-Market-State-and-Trends-report-2020. pdf (accessed on 23 October 2021).

30. Kurmayer, N.J. Germany to Invest $€ 8$ bn in Large-Scale Hydrogen Projects. 2021. Available online: https:/ /www.euractiv.com/s ection/energy-environment/news/germany-to-invest-e8-bn-in-large-scale-hydrogen-projects/ (accessed on 23 October 2021)

31. Darvas, Z.; Domínguez-Jiménez, M.; Devins, A.I.; Grzegorczyk, M.; Guetta-Jeanrenaud, L.; Hendry, S.; Hoffmann, M.; Lenaerts, K.; Schraepen, T.; Tzaras, A.; et al. European Union Countries' Recovery and Resilience Plans. Available online: https://www.br uegel.org/publications/datasets/european-union-countries-recovery-and-resilience-plans/ (accessed on 23 October 2021).

32. European Commission. NextGenerationEU: European Commission Endorses Germany's Recovery and Resilience Plan. Available online: https:/ / ec.europa.eu/commission/presscorner/detail/en/ip_21_3133 (accessed on 23 October 2021).

33. Verordnung zur Umsetzung des Erneuerbare-Energien-Gesetzes 2021 und zur Änderung Weiterer Energierechtlicher Vorschriften. 19 May 2021. Available online: https:/ / dserver.bundestag.de/btd/19/297/1929793.pdf (accessed on 23 October 2021).

34. Bundesministerium der Justiz und für Verbraucherschutz. Gesetz für den Ausbau Erneuerbarer Energien (Erneuerbare-EnergienGesetz-EEG 2021). Available online: https:/ /www.gesetze-im-internet.de/eeg_2014/BJNR106610014.html\#BJNR106610014BJ NG001501128 (accessed on 23 October 2021).

35. Parr, M.; Minett, S. What Is the Real Cost of Green Hydrogen? 2020. Available online: https://www.euractiv.com/section/energ y/opinion/what-is-the-real-cost-of-green-hydrogen/ (accessed on 23 October 2021).

36. AleaSoft Energy Forecasting. Prices from Negative to Almost $€ 100 /$ MWh in the First Half of 2021 of the German Electricity Market. Available online: https: / / aleasoft.com/ prices-from-negative-to-almost-100-eur-mwh-first-half-2021-german-market/ (accessed on 23 October 2021).

37. ACER. High Energy Prices. October 2021. Available online: https://documents.acer.europa.eu/en/The_agency/Organisation/ Documents/Energy\%20Prices_Final.pdf?fbclid=IwAR0r_UV60u2laqqWf45IczfeggQvXNzGyeH9jcFCIy9BwXoM0Sc0NWmis Fg (accessed on 23 October 2021).

38. Appunn, K. Government Defines “Green Hydrogen”, Decides Rules for Rapid Market Ramp-Up. 2021. Available online: https:/ / www.cleanenergywire.org/news/government-defines-green-hydrogen-decides-rules-rapid-market-ramp (accessed on 23 October 2021).

39. Agora Energiewende and Guidehouse (2021): Making Renewable Hydrogen Cost-Competitive: Policy Instruments for Green H2. Available online: https:/ / static.agora-energiewende.de/fileadmin/Projekte/2020/2020_11_EU_H2-Instruments/A-EW_223_ H2-Instruments_WEB.pdf (accessed on 8 December 2021).

40. Green Car Congress. Energy, Technologies, Issues and Policies for Sustainable Mobility. Germany Investing €8B+ in 62 Large-Scale Hydrogen Projects; “We Are Making Germany a Hydrogen Country”. 2021. Available online: https:/ /www.greencarcongress.c om/2021/05/20210529-germanyh2.html (accessed on 23 October 2021).

41. Clifford Chance. Focus on Hydrogen: Germany Implements First Pure Hydrogen Midstream Regulation and Introduces Definition for Green Hydrogen. Available online: https:/ / www.cliffordchance.com/content/dam/cliffordchance/briefings/202 1/06/focus-on-hydrogen-germany-implements-first-pure-hydrogen-midstream-regulation.pdf (accessed on 25 October 2021).

42. EUR-Lex. Access to European Union Law. Consolidated Text: Directive 2009/73/EC of the European Parliament and of the Council of 13 July 2009 Concerning Common Rules for the Internal Market in Natural Gas and Repealing Directive 2003/55/EC. Available online: https:/ / eur-lex.europa.eu/legal-content/EN/TXT/?uri=CELEX\%3A02009L0073-20190523 (accessed on 25 October 2021).

43. Eversheds Sutherland. Germany Sets Regulatory Framework for Green Hydrogen Production and Hydrogen Grid Projects. 6 July 2021. Available online: https://www.eversheds-sutherland.com/global/en/what/articles/index.page?ArticleID=en /Energy/Germany_sets-regulatory-framework-for-green-hydrogen-production-and-hydrogen-grid-projects (accessed on 25 October 2021).

44. Bundesministerium für Wirtschaft und Energie. Bundesregierung Verabschiedet Entwurf der Wasserstoffnetzentgeltverordnung. 22 September 2021. Available online: https:/ / www.bmwi.de/Redaktion/DE/Pressemitteilungen/2021/09/20210922-bundesreg ierung-verabschiedet-entwurf-der-wasserstoffnetzentgeltverordnung.html (accessed on 25 October 2021).

45. Verkhovna Rada of Ukraine. Legislation of Ukraine. Law on Alternative Types of Liquid and Gas Fuel (Закон України«Про АльтернативніВидиПалива»). Available online: https:/ / zakon.rada.gov.ua/laws/show/1391-14?lang=en\#Text (accessed on 25 October 2021).

46. RGC Hydrogen Project. Available online: https://rgc.ua/en/cleanenergy (accessed on 11 November 2021).

47. Економічна Правда. Водень Ближче до Людей. В Україні Два села Перейдуть на ОпаленняВоднем. 16 Магсh 2021. Available online: https:/ / www.epravda.com.ua/projects/greendeal/2021/03/16/671950/ (accessed on 25 October 2021).

48. Міністерство Енергетики України. Міненерго Приєдналось до Європейського Альянсу з Чистого Водню. 17 Јune 2021. Available online: http://mpe.kmu.gov.ua/minugol/control/publish/article?art_id=245548876 (accessed on 25 October 2021).

49. ENTSOG. Hydrogen Project Visualisation Platform. Overview of Hydrogen Projects along the Emerging Value-Chain in Europe. Available online: https:// h2-project-visualisation-platform.entsog.eu/?fbclid=IwAR2DOdmN7cq-5twEcacmVWP8S44V8mLa REXihidO4rfsEEFV0VJxSn_uCD4 (accessed on 25 October 2021). 
50. Energy Community. Hydrogen Study Explores Potential of Technologies and Utilisation in the Energy Community. 17 June 2021. Available online: https://www.energy-community.org/news/Energy-Community-News/2021/06/17a.html?fbclid=IwAR2t Fs_Gx97Kkn1JV3qGyi1geTk2NhY1ItopbHGlEulz5FwqQB5Fqg-Rw6s (accessed on 25 October 2021).

51. United Nations Climate Change. Ukraine 2050_Low Emission Development Strategy. Available online: https://unfccc.int/sites / default/files/resource/Ukraine_LEDS_en.pdf (accessed on 25 October 2021).

52. Міністерство Захисту Довкілля та Природних Ресурсів України. Концепція«зеленого» Енергетичного Переходу України до 2050 року. 21 January 2020. Available online: https:/ / mepr.gov.ua/news/34424.html (accessed on 25 October 2021).

53. UKRAÏHСЬKA ENERGETИКА. Уряд Отримав Драфт Інтегрованого Національного Плану з Енергетики та Клімату. 29 July 2020. Available online: https:/ / ua-energy.org/uk/posts/uriad-otrymav-draft-intehrovanoho-natsionalnoho-planu-z -enerhetyky-ta-klimatu (accessed on 25 October 2021).

54. Verkhovna Rada of Ukraine. Legislation of Ukraine. Розпорядження Кабінету Міністрів України«Про ЗатвердженняПлану Заходів зВиконання Річної НаціональноїПрограми під егідою Комісії Україна-НАТО на 2021 рік та Показників Ефективності їїВиконання» від16 Червня2021 р. № 690-p. Available online: https://zakon.rada.gov.ua/laws/show /690-2021 -\%D1\%80?lang=en\#Text (accessed on 25 October 2021).

55. Gemeinsame Absichtserklärung Zwischen der Regierung der Ukraine und der Regierung der Bundesrepublik Deutschland über den Aufbau Einer Energiepartnerschaft. Available online: https://www.bmwi.de/Redaktion/DE/Downloads/G/gemeinsameabsichtserklaerung-zwischen-der-regierung-der-ukraine-und-der-regierung-der-bundesrepublik-deutschland-ueber-den-auf bau-einer-energiepartnerschaft.pdf?_blob=publicationFile\&v=4 (accessed on 25 October 2021).

56. ЕнергетичнеПартнерство Energy Partnership Ukraine-Germany. Deutsch-Ukrainische Energiepartnerschaft. Publikation Anlässlich des Ersten Deutsch-Ukrainischen Energietages. Available online: https:/ /www.energypartnership-ukraine.org/filea dmin/user_upload/ukraine/media_elements/German-Ukrainian_EP_owc.pdf (accessed on 25 October 2021).

57. ЕнергетичнеПартнерство Energy Partnership Ukraine-Germany. About the Energy Partnership. Available online: https: //www.energypartnership-ukraine.org/home/about/ (accessed on 1 November 2021).

58. УрядовийПортал. ЄдинийВеб-Портал ОрганівВиконавчої вади УКРАЇНИ. В Міненергетики Розроблено триВажливих Документи дляПідготовкиВодневоїСтратегії України. 21 April 2021. Available online: https://www.kmu.gov.ua/n ews/v-minenergetiki-rozrobleno-tri-vazhlivih-dokumenti-dlya-pidgotovki-vodnevoyi-strategiyi-ukrayini (accessed on 1 November 2021).

59. Draft Roadmap for Production and Use of Hydrogen in Ukraine. Available online: https://unece.org/sites/default/files/202103/Draft\%20Roadmap\%20for\%20production\%20and\%20use\%20of\%20hydrogen\%20in\%20Ukraine_Final\%20.pdf (accessed on 1 November 2021).

60. Verkhovna Rada of Ukraine. Legislation of Ukraine. Рішення Ради Національної Безпеки і Оборони України«Про Заходи з Нейтралізації загроз в ЕнергетичнійСфері» від30 Липня2021 Року. Available online: https:/ /zakon.rada.gov.ua/laws/sho w/n0056525-21?lang=en\#Text (accessed on 1 November 2021).

61. Draft Roadmap for the Use of Hydrogen in Ukraine in Road Transport. Available online: https://unece.org/sites/default/files /2021-05/Draft\%20Roadmap\%20for\%20the\%20use\%20of\%20hydrogen\%20in\%20Ukraine\%20in\%20road\%20transport_ENG2 021.pdf (accessed on 1 November 2021).

62. Verkhovna Rada of Ukraine. Legislation of Ukraine. Розпорядження Кабінету Міністрів України«Про СхваленняСтратегії Енергетичної Безпеки» від4 Серпня2021 № 907-p. Available online: https:/ / zakon.rada.gov.ua/laws/show /907-2021-\%D1\%8 0 ?lang=en\#Text (accessed on 1 November 2021).

63. Verkhovna Rada of Ukraine. Legislation of Ukraine. Розпорядження Кабінету Міністрів України«Про Схвалення ЕнергетичноїСтратегії України на період до 2035 року«Безпека, Енергоефективність, Конкурентоспроможність» від18 Серпня2017 № 605-p. Available online: https:/ / zakon.rada.gov.ua/laws/show /605-2017-\%D1\%80?lang=en\#Text (accessed on 1 November 2021).

64. УрядовийПортал. ЄдинийВеб-Портал ОрганівВиконавчої вади України. Енергетична Стратегія-2050 Розроблятиметься Міненерго Спільно з Іншими Міністерствами та БританськимиПартнерами. 14 July 2021. Available online: https: //www.kmu.gov.ua/news/energetichna-strategiya-2050-rozroblyatimetsya-minenergo-spilno-z-inshimi-ministerstvami-tabritanskimi-partnerami (accessed on 1 November 2021).

65. Міністерство Енергетики України. ГерманГалущенко: Енергетична Стратегія-2050 маєСпиратися на РеальніПоказники і бути Максимально Практичною. 4 August 2021. Available online: http://mpe.kmu.gov.ua/minugol/control/publish/article ?art_id=245563004 (accessed on 1 November 2021).

66. Міністерство Енергетики України. Україна береАктивну Участь уСтворенніГлобального РинкуВодневої Енергетики, —Заступник Міністра. 2 July 2021. Available online: http://mpe.kmu.gov.ua/minugol/control/publish/article?art_id=245553 332 (accessed on 1 November 2021).

67. Міністерство Енергетики України. Робоча Група з РозробкиВодневоїСтратегії УкраїниПровела Перше Засідання. 12 August 2021. Available online: http:/ / mpe.kmu.gov.ua/minugol/control/publish/article?art_id=245565207 (accessed on 1 November 2021).

68. ДП «УкрНДЦ». Накази щодо Діяльності Технічних Комітетів2020 Червень. Available online: http:/ /uas.org.ua/ua/servic es/standartizatsiya/tehnichni-komiteti-ukrayini/nakazi/2020-2/cherven/ (accessed on 1 November 2021). 
69. Verkhovna Rada of Ukraine. Legislation of Ukraine. Наказ Державного Підприємства «Український Науково-Дослідний і Навчальний центрПроблемСтандартизації, Сертифікації та Якості» «Про Прийняття НаціональнихСтандартів" від19 April 2021 № 146. Available online: https://zakon.rada.gov.ua/rada/show/v0146774-21?lang=en\#Text (accessed on 1 November 2021).

70. Dixigroup. Правова база для РозвиткуВодневої Енергетики: Міжнародний Досвід та Ситуація в Україні. Аvailable online: https:/ /dixigroup.org/wp-content/uploads/2021/09/dixi_group_hydrogen_legal_policy-brief_final.pdf (accessed on 1 November 2021).

71. Rybak, Y. Green Hydrogen Perspectives. Hydrogen Projects. Presented at the 12th European-Ukrainian Energy Day, Kyiv, Ukraine, 10 June 2021. Available online: https:/ / cutt.ly /6nGvZig (accessed on 1 November 2021).

72. ExPro Consulting. Група КомпанійMCL ГотуєПроектВЕС зВиробництвом«Зеленого» Водню у Рівненській Області. 21 April 2021. Available online: https:/ / expro.com.ua/novini/grupa-kompany-mcl-gotu-proekt-ves-z-virobnictvom-zelenog o-vodnyu-u-rvnensky-oblast (accessed on 1 November 2021).

73. ZAXID.NET. Чурилова, K. Перший Зелений. Перший в Україні завод зВиробництва Зеленого Водню Збудують на Львівщині. 8 September 2021. Available online: https:/ / zaxid.net/pershiy_zeleniy_n1525661?fbclid=IwAR2eFMzjv6CskzDw pHpt2z3Q6itrW0Y7592agNDVN0TGbYckZByAI42IpfM (accessed on 1 November 2021).

74. NAFTOGAZ. Naftogaz and RWE Sign Memorandum of Understanding on Hydrogen. 22 August 2021. Available online: https: / / www.naftogaz.com/www/3/nakweben.nsf/0/25324F6E9CFED741C2258739001F677D?OpenDocument\&year=2021\& month=08\&nt=News\& (accessed on 1 November 2021).

75. Hydrogen Europe. Hydrogen Production \& Water Consumption. December 2020. Available online: https://www.hydrogeneuro pe.eu/wp-content/uploads/2021/07/Hydrogen-production-water-consumption_fin.pdf (accessed on 1 November 2021).

76. Joint Press Release. Overview of the Core Elements of the Funding Guideline to Support the International Establishment of Generating Installations for Green Hydrogen. 5 October 2021. Available online: https://www.bmwi.de/Redaktion/EN/Pressem itteilungen/2021/10/20211004-overview-of-the-core-elements-of-the-funding-guideline-to-support-the-international-establi shment-of-generating-installations-for-green-hydrogen.html (accessed on 11 November 2021).

77. Discussion Paper by the Energy Community Secretariat on Implementation of the Guarantees of Origin System in the Energy Community DP 02/2021/17 Mar 2021. Available online: https:/ / energy-community.org/dam/jcr:0f809f7f-d2da-4592-b171-ca44 545edda7/DP-02-2021_GoO_16032021.pdf (accessed on 1 November 2021).

78. Verkhovna Rada of Ukraine. Legislation of Ukraine. Постанова Кабінету Міністрів України«Про затвердженняПорядкуВидачі, Використання та Припинення діїГарантіїПоходження Електричної енергії для суб'єктівГосподарювання, що Виробляють Електричну Енергію зАльтернативних джерел енергії від24 липня2013 р. № 771. Available online: https: / / zakon.rada.gov.ua/laws/show/771-2013-\%D0\%BF?lang=en\#Text (accessed on 1 November 2021).

79. Ukraїнська Energeтика. В Україні ХочутьСтворитиПлатформу зВидачіГарантійПоходження Енергії. 10 August 2021. Available online: https:/ / ua-energy.org/uk/posts/v-ukraini-khochut-stvoryty-platformu-z-vydachi-harantii-pokhodzhenn ia-enerhii (accessed on 1 November 2021).

80. Kustova, I.; Egenhofer, C. How Black Sea Offshore Wind Power Can Deliver a Green Deal for this EU Region. CEPS Policy Insight PI2020-26/October 2020. Available online: https:/ / www.ceps.eu/wp-content/uploads/2020/10/PI2020-26_Black-Sea-offshore -wind-power.pdf (accessed on 1 November 2021).

81. Укренерго Національна Енергетична Компанія. Звіт з ОцінкиВідповідності(Достатності) ГенеруючихПотужностей дляПокриттяПрогнозованого Попиту на Електричну Енергію та Забезпечення Необхідного Резерву у2020 Році. Available online: https:/ / ua.energy/wp-content/uploads/2021/06/Zvit-z-otsinky-vidpovidnosti-dostatnosti-generuyuchyh-potuzhnos tej-dlya-pokryttya-prognozovanogo-popytu-na-elektrychnu-energiyu-ta-zabezpechennya-neobhidnogo-rezervu-u-2020.pdf (accessed on 1 November 2021).

82. Eichman, J.; Harrison, K.; Peters, M. Novel Electrolyzer Applications: Providing More Than Just Hydrogen. National Renewable Energy Laboratory. 2014. Available online: https://www.nrel.gov/docs/fy14osti/61758.pdf (accessed on 1 November 2021).

83. Hydrogenics Successfully Completes Utility-Scale Grid Stabilization Trial with Ontario's Independent Electricity System Operator. Available online: https:/ / www.sec.gov/Archives/edgar/data/1119985/000117184311001819/newsrelease.htm (accessed on 1 November 2021).

84. Wind-to-Hydrogen Energy Pilot Project: Basin Electric Power Cooperative. Final Report (for the Period of September 1, 2004, through December 31, 2008). June 2009. Available online: https://digital.library.unt.edu/ark:/67531/metadc928340/m2/1/hig h_res_d/951588.pdf (accessed on 1 November 2021).

85. Orkney Islands Council. H2 in Orkney-The Hydrogen Islands. Available online: https://www.orkney.gov.uk/Service-Director y/Renewable/h2-in-orkney-the-hydrogen-islands.htm (accessed on 1 November 2021).

86. Fuel Cells and Hydrogen Joint Undertaking. Building Innovative Green Hydrogen Systems in an Isolated Territory: A Pilot for Europe. Available online: https:/ / www.fch.europa.eu/project/building-innovative-green-hydrogen-systems-isolated-territor y-pilot-europe (accessed on 1 November 2021).

87. Gérard, F.; van Nuffel, L.; Smit, T.; Yearwood, J.; Černý, O.; Michalski, J.; Altmann, M. Opportunities for Hydrogen Energy Technologies Considering the National Energy \& Climate Plans. Final Report. August 2020. Available online: https:/ / www.fch.europa .eu/sites/default/files/file_attach/Final\%20Report\%20Hydrogen\%20in\%20NECPs\%20\%28ID\%209501746\%29.pdf (accessed on 1 November 2021). 
88. Nijhuis, C. Germany Passes New Climate Action Law, Pulls forward Climate Neutrality Target to 2045. 25 June 2021. Available online: https:/ / www.cleanenergywire.org/news/germany-passes-new-climate-action-law-pulls-forward-climate-neutralitytarget-2045 (accessed on 1 November 2021).

89. Prognos, A.G.; Öko-Institut e.V.; Wuppertal Institut für Klima, Umwelt, Energie gGmbH. Towards a Climate-Neutral Germany by 2045. How Germany Can Reach Its Climate Targets before 2050 Executive Summary Conducted for Stiftung Klimaneutralität, Agora Energiewende and Agora Verkehrswende. 2021. Available online: https://static.agora-energiewende.de/fileadmin/Proje kte/2021/2021_04_KNDE45/A-EW_213_KNDE2045_Summary_EN_WEB.pdf (accessed on 1 November 2021).

90. Bianko, E.; Hawila, D. Solving the Chicken and Egg Problem: Auctions for Green Hydrogen. IRENA, 12 September 2021. Available online: https://www.irena.org/newsroom/expertinsights/2021/Sep/Auctions-for-Green-Hydrogen (accessed on 1 November 2021).

91. UA Transmission System Operator. КомпаніїГазового СекторуПредставляють Центрально-ЄвропейськийВодневий Коридор. 23 September 2021. Available online: https:/ tsoua.com/news/kompaniyi-gazovogo-sektoru-predstavlyayut-czentra lno-yevropejskyj-vodnevyj-korydor/ (accessed on 1 November 2021). 